\title{
The effect of calabash chalk on some hematological parameters in female adult Wistar rats
}

\author{
Kalabaş tebeşiri (Calabash chalk) dişi yetişkin Wistar sıçanların bazı \\ hematolojik parametreleri üzerindeki etkisi
}

\author{
Amabe Otoabasi Akpantah, Ofon Samuel Ibok, Moses Bassey Ekong, Mokutima \\ Amarachi Eluwa, Theresa Bassey Ekanem \\ Department of Anatomy, University of Calabar, Calabar, Nigeria
}

\begin{abstract}
Objective: Calabash chalk is a naturally occurring mineral consumed among the Nigerian community for pleasure and commonly by pregnant women as a remedy for morning sickness. Reports have shown that it contains different toxic substances, with lead being the most abundant. This study was therefore undertaken to ascertain the effect of two commonly available preparations of this chalk on some hematological parameters.

Materials and Methods: Twenty-four adult female Wistar rats with average weight of $100 \mathrm{~g}$ were assigned into three groups $(1,2,3)$. Group 1 served as the control and the animals received distilled water, while Groups 2 and 3 were treated by oral gavage with $40 \mathrm{mg} / \mathrm{kg}$ of non-salted (NSCC) and salted calabash chalk (SCC), respectively, for 14 days.

Results: The hemoglobin (Hb) concentration and red blood cell (RBC) count were significantly $(p<0.05,0.001$ respectively) lower in the NSCC group, while erythrocyte sedimentation rate (ESR) was significantly $(p<0.05)$ higher in the NSCC group compared to the control. There were no significant differences in packed cell volume (PCV), white blood cell (WBC) and platelet (PI) counts compared to the control. The SCC group presented no significant difference in all blood count parameters compared to the control.

Conclusion: This infers that calabash chalk, particularly the non-salted form, alters the normal concentration of $\mathrm{Hb}, \mathrm{RBC}$ and $\mathrm{Pl}$ counts, and ESR, as observed in the female Wistar rats studied.

(Turk J Hematol 2010; 27: 177-81)

Key words: Calabash chalk, blood parameters, wistar rat

Received: December 19, 2008

Accepted: January 28, 2010

\section{Özet}

Amaç: Kalabaş tebeşiri, genellikle gebe ve diğer kadınlar tarafından keyfi olarak ve sabah bulantısını iyileştirmek için tüketilen, doğan oluşumlu bir mineraldir. Başta kurşun olmak üzere farklı toksik maddeler içerdiği raporlarda gösterilmiştir. Dolayısıyla bu çalışmada, bu taşın en yaygın iki preparatının bazı hematolojik parametreler üzerindeki etkisinin belirlenmesi amaçlanmıştır.
\end{abstract}


Yöntem ve Gereçler: Ortalama 100 g ağırlığında 24 yetişkin dişi Wistar sıçanı üç gruba $(1,2$ ve 3) ayrılmıştır. Grup 1 kontrol grubu olup, hayvanlara distile su verilmiş ve grup 2 ve 3, 14 gün süreyle her biri $40 \mathrm{mg} / \mathrm{kg}$ tuzsuz (NSCC) ve tuzlu Kalabaş tebeşiri (SCC) ile birlikte oral besleme yoluyla tedavi edilmiştir.

Bulgular: Hemoglobin (Hb) konsantrasyonu ve kırmızı kan hücresi (RBC) sayımı anlamlı derecede NSCC grubunda düşüktü (Sırasıyla $\mathrm{P}<0.05,0.001$ ), eritrosit sedimentasyın hızı da kontrol grubuna oranla anlamlı olarak yüksekti $(p<0.05)$. Hematokrit, beyaz kan hücresi ve trombosit sayımlarında kontrol grubuna gore anlamlı değişiklik olmamıştır. SCC grubunun tüm kan parametrelerinde kontrol grubuna göre anlamlı değişiklik gözlemlenmemiştir.

Sonuç: Özellikle tuzsuz olan Kalabaş tebeşiri, incelenen dişi Wistar sıçanlarda normal Hb konsantrasyonu, RBC ve PI sayımlarını ve ESR değerini değiştirdiği gösterilmiştir.

(Turk J Hematol 2010; 27: 177-81)

Anahtar kelimeler: Kalabaş tebeşiri, kan parametreleri, wistar sıçan

\section{Introduction}

Calabash chalk is traditionally consumed by Nigerian communities for pleasure and as a remedy for morning sickness [1]. Though it is not a conventional food, it is reported to be consumed mostly by pregnant and breast-feeding women [1,2].

This chalk is a naturally occurring mineral, which is chiefly composed of fossilized seashells. It may also be prepared from clay and mud, which may be mixed with other ingredients, including sand, wood ash and sometimes salt. The resulting product is molded and then heated to produce the final product [3].

Calabash chalk is also known as Calabar stones, La Craie or Argile in French, Nzu by the Igbos and Ndom by the Efiks/Ibibios of Nigeria, and Mabele by the Lingala of Congo. It is sold in blocks, pellets and powder forms [4]. This chalk is composed of aluminum silicate hydroxide from the kaolin clay group with the possible formula: $\mathrm{Al}_{2} \mathrm{Si}_{2} \mathrm{O}_{5} \mathrm{OH}_{4}$. It has been tested to contain lead and arsenic [1-3,5]. The quantity of lead is reported to be approximately 40 $\mathrm{mg} / \mathrm{kg}$, with other organic pollutants being alpha lindane, endrin, endosulphan 11, and P, P1- DD [5].

Exposure to these higher levels of lead and also arsenic by pregnant and breast-feeding women poses a risk to the mental development of their unborn babies and breast-feeding infants, respectively [1,2]. Reports such as these and others, reporting cancers of the urinary bladder, lungs and skin [2], led us to investigate the effect of both salted (SCC) and non-salted calabash chalk (NSCC) on some blood parameters in adult female Wistar rats.

\section{Material and Methods}

Twenty-four adult female Wistar rats with an average weight of $100 \mathrm{~g}$ were used for this study after acclimatization for two weeks in the Animal House of the Department of Anatomy, University of Calabar, Nigeria.

The animals were equally divided into three groups as: Group 1, which served as the control and received distilled water, and Groups 2 and 3, which were treated with a solution of $40 \mathrm{mg} / \mathrm{kg}$ of NSCC and SCC, respectively.

The two forms of calabash chalk were purchased as blocks from a local market in Calabar, Nigeria, and were ground into powder. One gram of each powder was dissolved in $100 \mathrm{ml}$ of distilled water. Then, $40 \mathrm{mg} / \mathrm{kg}$ equivalent of the chalk solutions was administered to the experimental animals. The treatment was by oral gavage, once daily, and lasted for 14 days.

On the $15^{\text {th }}$ day, the animals were humanely sacrificed using chloroform anesthesia, and blood was aspirated through cardiac puncture and stored for a limited time in heparinized tubes for hematological assay [6-8]. Blood parameters assayed included hemoglobin $(\mathrm{Hb})$ concentration, packed cell volume (PCV), erythrocyte sedimentation rate (ESR), and red blood cell (RBC), white blood cell (WBC) and platelet $(\mathrm{Pl})$ counts.

\section{Statistical analysis}

One way analysis of variance (ANOVA) was applied to compare the relationship of the groups, and Dunnett post-hoc test was used to compare the 
experimental groups and the control. All values were presented as mean \pm standard error of mean (SEM), and values were considered significant at $\mathrm{p}<0.05$.

\section{Results}

The $\mathrm{Hb}$ concentrations were lower in the treatment groups, and the difference was significant $(p<0.01)$ in the $40 \mathrm{mg} / \mathrm{kg}$ NSCC group compared to the control and SCC groups.

The PCV was lowest in the group treated with 40 $\mathrm{mg} / \mathrm{kg}$ NSCC, but the difference was not significant when compared to the control and the SCC groups.

The ESR showed a significant increase $(\mathrm{p}<0.01)$ in the group treated with $40 \mathrm{mg} / \mathrm{kg}$ NSCC when compared to the control and SCC groups; however, there was no difference between the SCC group and the controls.

The RBC count was significantly lower $(\mathrm{p}<0.05)$ in the NSCC group when compared to the control and SCC groups, but there was no difference between the SCC and the control groups.

The WBC count revealed no significant difference among the groups. The NSCC group had a slightly higher count.

The Pl count also showed no significant difference between the control and the treatment groups, though Pl count was higher in the controls than both treatment groups.

These results are shown in Table 1.

\section{Discussion}

The $\mathrm{Hb}$ concentration was lower in the group treated with $40 \mathrm{mg} / \mathrm{kg} \mathrm{NSCC}$, while the concentration in the SCC group was not different from the controls. Hb determines the oxygen-carrying capacity of the RBC. A decrease in $\mathrm{Hb}$ may be due to inability of the RBCs to incorporate iron or due to the destruction of iron already contained within the RBCs [9]. Our study is in line with previous reports [10-12], which reported decreased $\mathrm{Hb}$ after exposure to lead compound and arsenic.

The PCV showed no significant difference among the groups, though it was lower in the group treated with $40 \mathrm{mg} / \mathrm{kg}$ NSCC compared to the others. PCV measures the percentage of red cells in total blood volume. The lack of difference between the treatment groups and the controls may be because the chalk may not have affected the total RBC volume in whole blood. This is in variance with previous reports [10-12] that showed significantly decreased PCV after treatment with lead compound.

The ESR of the NSCC group was significantly higher $(p<0.05)$ than in the control and the SCC groups. ESR is the rate at which RBCs precipitate in one hour [13]. Anemia increases ESR. Anemia may have caused the increase in ESR in the NSCC group.

Red blood cell (RBC) count of the NSCC group was significantly lower $(p<0.001,0.01)$ than in the control and SCC groups, respectively. RBC count estimates the number of RBCs per liter of blood. A reduced $\mathrm{RBC}$ count may indicate anemia. This is

Table 1. The parameters measured in the control, non-salted and salted calabash chalk groups

\begin{tabular}{|c|c|c|c|c|c|c|}
\hline \multirow{2}{*}{$\begin{array}{l}\text { GROUPS } \\
\qquad(n=8)\end{array}$} & \multicolumn{6}{|c|}{ BLOOD PARAMETERS } \\
\hline & $\begin{array}{c}\mathrm{Hb} \\
(\mathrm{g} / \mathrm{dl})\end{array}$ & $\begin{array}{l}\text { PCV } \\
(\%)\end{array}$ & $\begin{array}{c}\text { ESR } \\
(\mathbf{m m} / \mathbf{h r})\end{array}$ & $\begin{array}{c}\text { RBC } \\
\left(\mathrm{X} 10^{6} / \mathrm{mm}^{3}\right)\end{array}$ & $\begin{array}{c}\text { WBC } \\
\left(\mathrm{X} 10^{3} / \mathrm{mm}^{3}\right)\end{array}$ & $\begin{array}{c}\mathrm{Pl} \\
\left(\mathrm{X} 10^{5} / \mathrm{mm}^{3}\right)\end{array}$ \\
\hline $\begin{array}{c}1 \\
\text { (Control) }\end{array}$ & $12.50 \pm 0.20$ & $34.00 \pm 0.58$ & $3.67 \pm 0.33$ & $5.99 \pm 0.02$ & $5.55 \pm 0.21$ & $4.6 \pm 0.12$ \\
\hline $\begin{array}{c}2 \\
40 \mathrm{mg} / \mathrm{kg} \\
\text { of NSCC }\end{array}$ & $11.25 \pm 0.20 * *$ & $26.67 \pm 4.18^{\mathrm{NS}}$ & $5.67 \pm 0.33^{* *}$ & $5.51 \pm 0.80^{\mathrm{NS}}$ & $5.77 \pm 0.15^{\mathrm{NS}}$ & $4.33 \pm 0.09^{\mathrm{NS}}$ \\
\hline $\begin{array}{c}3 \\
40 \mathrm{mg} / \mathrm{kg} \\
\text { of } \mathrm{SCC}\end{array}$ & $11.99 \pm 0.26^{\mathrm{NS}}$ & $34.67 \pm 1.33^{\mathrm{NS}}$ & $3.67 \pm 0.33^{b}$ & $5.97 \pm 0.01^{\mathrm{NS}}$ & $5.55 \pm 0.16^{\mathrm{NS}}$ & $4.57 \pm 0.13^{\mathrm{NS}}$ \\
\hline
\end{tabular}

Values are presented as mean \pm SEM

**Significantly different from control, at $\mathrm{p}<0.01$

bignificantly different from Group 2 , at $\mathrm{p}<0.01$

NS Not significantly different from control, at $p<0.05$

Hb: Hemoglobin concentration; PCV: Packed cell volume; NSCC: Non-salted calabash chalk; SCC: Salted calabash chalk; ESR: Erythrocyte sedimentation rate;

RBC: Red blood cell count; WBC: White blood cell count; Pl: Platelet count 
consistent with $\mathrm{Hb}$ in this study. It has also been reported that RBC count decreased after lead exposure [10], while arsenic-poisoned cattle showed decreased RBC count [12].

White blood cell (WBC) count estimates the total number of WBCs per liter of blood [14]. In this study, there was no significant difference between the treatment groups and the controls, though the group treated with the NSCC showed the highest value. This indicates that the NSCC has little effect on WBC count. This is in variance with a previous report in which there was decreased WBC in arsenic-poisoned cattle [12].

Our study is in line with previous reports [1012,15,16] that reported decreased RBC count, PCV and $\mathrm{Hb}$ after exposure to Jatropha curcas, vanadium, lead and its compound, and arsenic. However, this study is in variance with other works [12,17] that reported an increase in WBC when chlordecone was administered to male Sprague-Dawley rats [17] and when arsenic- poisoned cattle blood parameters were evaluated.

Calabash chalk contains lead and arsenic [1-3,5]. This has been implicated in the disruption of the biosynthesis of $\mathrm{Hb}$ and anemia, increase in blood pressure, and kidney, liver and brain and other neurologic damage $[9-12,18,19]$. These may have been the reasons for the decreased $\mathrm{Hb}, \mathrm{PCV}$ and RBC and $\mathrm{Pl}$ counts as seen in the group treated with $40 \mathrm{mg} /$ kg NSCC.

The results obtained from the group treated with $40 \mathrm{mg} / \mathrm{kg}$ SCC showed no significant differences from the results in the control group, unlike the NSCC group. Could the addition of salt lead to some chemical reaction with the toxic substances, which may have modulated the effect of these substances in this study? This calls for a further investigation on the toxicity of these two forms of calabash chalk and the possible teratogenic effects as well since it is consumed by pregnant women.

In conclusion, our investigation revealed that calabash chalk, particularly the non-salted form, is detrimental on some hematological parameters in female Wistar rats.

\section{Conflict of Interest}

No author of this paper has a conflict of interest, including specific financial interests, relationships, and/or affiliations relevant to the subject matter or materials included in this manuscript.

\section{References}

1. Campbell H. Calabash chalk (Calabar stone, La Craie, Argile, Nzu, Mabele). Chief Medical Officer, CB Upper Newtownards Road, Belfast: 2002.

2. Health Canada. Calabash chalk may pose health risk for pregnant and breastfeeding women. Advisory 2007136 in www.hc-sc.gc.ca Accessed Oct 2008.

3. Food Standards Agency. Lead contamination of Calabash chalk category B: For Action. 2002. URL: www.food.gov.uk. Accessed December 2, 2008.

4. Northumberland Country Council Press Release Archives. Product warning: Excess lead in Calabash chalk. Country Hall. Morpheth. Accessed December 2, 2008.

5. Dean JR, Deary ME, Gbefa BK, Scott WC. Characterization and analysis of persistent organic pollutants and major, minor and trace elements in Calabash chalk. Chemosphere 2004;57:21-5.

6. Mapherson RA, Pincus MR. Henry's Clinical Diagnosis and Management by Laboratory Methods. Philadelphia, PA: WB Saunders, 2007.

7. Hoffman RC, Benz EJ, Shattil SJ, Furie B, Cohen HJ. Hematology. Basic Principles and Practice. Philadelphia, PA: Churchill Livingstone, 2005.

8. Purves WK, Sadava D, Orians GH, Heller HC. Life: The Science of Biology (7th ed). Sunderland, MA: Sinauer Associates, 2004.

9. Lenntech. Chemical properties of lead - environmental effects of lead. URL: www.wikepedia.com. Accessed December 2, 2008.

10. Annabi BA, Nehdi A, Hajjaji N, Gharbi N, El-Fazaa S. Antioxidant enzymes activities and bilirubin level in adult rat treated with lead. C R Biol 2007;330:581-8.

11. Adeyemo OK, Funmilola A, Adedeji OB, Ajiboye OO. Acute toxicity of and blood profile of adult Clarias ngariepimes exposed to lead nitrate. Internet $\mathrm{J}$ Hematol 2008;4.

12. Rana T, Sarkar S, Mandal TK, Batabyal S. Haematobiochemical profiles of affected cattle at arsenic prone zone in Haringhata block of Nadia District of West Bengal in India. Internet J Hematol 2008;4.

13. Wikipedia. Erythrocyte sedimentation rate. URL: www. wikipedia.com. Accessed December 2, 2008.

14. My Dr. Full blood count. 2006. URL: www.mydr.com. Accessed December 2, 2008.

15. Oluwole FS, Bolarinwa AF. Jatropa curcus extract causes anaemia in rats. Phyther Res 1998;11:538-9.

16. Scibior A, Zaporowski J, Ostrowski J. Selected haematological and biochemical parameters of blood in rats after subchronic administration of vanadium and/or 
magnesium in drinking water. Arch Environ Contam Toxicol 2006;51:287-95.

17. Chetty KN, Fantroy IL, Landau G, Ivie GW. Lack of dietary calcium effect on chlordecone increased white blood cell count, total iron, and iron-binding capacity in serum of rat. Ecotoxicol Environ Safety 1996;33:268-70.

18. Hudson PV, Whittle DM, Wong PT, Borgmann U, Thomas RL, Chau YK, Nriagu JO, Hallet DJ. Lead con- tamination of the Great Lakes. Indianapolis, IN: John Wiley \& Sons, 1984.

19. Centers for Disease Control and Prevention. Managing elevated blood lead levels among young children. Recommendations from the Advisory Committee on Childhood Lead Poisoning Prevention. Atlanta, Georgia: US Department of Health \& Human Services, 2002. 